(c) Elsevier/INRA

Original article

\title{
Genetic variability in French populations of the Corsican mouflon (Ovis ammon musimon): analysis of 2 blood proteins and red-cell blood groups
}

\author{
C Montgelard ${ }^{1}$, TC Nguyen ${ }^{2}$, D Dubray ${ }^{3}$ \\ 1 Institut des Sciences de l'Évolution (URA 327 CNRS), Laboratoire de Paléontologie \\ des Vertébrés (EPHE), UM II, CC 64, 34095 Montpellier Cedex 5; \\ 2 INRA, Unité Polymorphisme Sanguin Ovin et Caprin, \\ Laboratoire des Groupes Sanguins, 78350 Jouy-en-Josas; \\ 3 Office National de la Chasse, CNERA, Faune de Montagne, BP 6074, \\ 34030 Montpellier Cedex 1, France
}

(Received 8 April 1993; accepted 11 February 1994)

Summary - Genetic variation in 7 French populations of the Corsican mouflon (Ovis ammon musimon) was investigated by red-cell blood-group typing and electrophoresis of hemoglobin and transferrin. The 7 populations included 3 that were captive, 3 established by introducing animals into the wild and 1 native population on Corsica. Raw data were treated by classical monofactorial indexes and multivariate analyses. These analyses revealed no significant reduction of genetic variability in either the captive or the introduced feral populations, although the number of founder individuals was very low in both cases. The maintenance of genetic variation is explained by the diverse geographical origins and by the genetic divergence of the founder individuals. Moreover, multivariate analyses revealed a genetic structure related to the origin of the founder populations. Longterm resilience of gene combinations of blood factors and absence of gene flow between populations are suggested as the factors explaining conservation of the genetic make-up of the founder individuals over several generations. Finally, the presence of the hemoglobin A allele in 4 of the populations allows discussion of the emergence of the mouflon by feralization from archaic sheep.

Ovis ammon musimon / red-cell blood groups / genetic variability / origin of populations / multivariate analysis

Résumé - Variabilité génétique chez les populations françaises du mouflon de Corse (Ovis ammon musimon) : analyse de 2 protéines du sang et des groupes sanguins érythrocytaires. La variabilité génétique de 7 populations françaises du mouflon de Corse (Ovis ammon musimon) est analysée à partir de l'étude du polymorphisme 
de l'hémoglobine, de la transferrine et des facteurs antigéniques des groupes sanguins érythrocytaires. Trois populations élevées en captivité, 3 populations introduites sur le continent et la population autochtone de Corse ont été analysées. Les données sont traitées par des indices monofactoriels et des analyses multivariées. Ces analyses ne révèlent pas de réduction de la variabilité génétique, ni pour les populations en captivité ni pour les populations sauvages introduites, bien que ces populations aient été fondées à partir d'un petit nombre d'individus. Le maintien de la variabilité est expliqué par la diversité de l'origine géographique et la divergence génétique des animaux fondateurs. La différenciation génétique observée entre les populations est en outre corrélée avec l'origine des individus introduits. Ce résultat est expliqué en invoquant l'absence de flux génique entre les populations et par la conservation de combinaisons de gènes (phénogroupes des groupes sanguins) sur plusieurs générations. La présence de l'allèle $A$ de l'hémoglobine permet aussi d'aborder la question de l'origine du mouflon par marronnage.

Ovis ammon musimon / groupes sanguins érythrocytaires / variabilité génétique / origine des populations / analyses multivariées

\section{INTRODUCTION}

The present distribution of the Corsican mouflon (Ovis ammon musimon) is essentially the result of mainland introductions from native populations on Corsican and Sardinian islands (Tomiczek, 1985; Uloth and Prien, 1985). Numerous European countries (from Spain to ex-USSR) and other parts of the world (USA, Kerguelen Islands) also harbor introduced mouflon populations (Nadler et al, 1971; ONC, 1985). In France, introductions took place in the years 1950-1965 and wild-living populations are now present in the mountains of the Alps, the Pyrénées, the Cévennes and the Massif Central.

The genetic variability of the Corsican mouflon has been assessed mainly by means of electrophoretic analyses, which revealed large differences between populations. Stratil and Boback (1988) analyzed 90 mouflons from Czechoslovakia for 10 blood proteins, 5 of which were polymorphic (transferrin, hemopexin, esterase-A, X-protein and catalase). A similar result was obtained by Randi et al (1991) who found 4 polymorphic loci (hexokinase, isocitrate deshydrogenase, glucose-6-phosphate dehydrogenase and malico-enzyme) among the 33 loci scored in 10 Italian individuals. On the other hand, the study of Hartl (1990) revealed a very low biochemical variability in 4 populations from the Austrian Alps: only one locus (esterase-2) of the 31 protein systems studied was polymorphic. The difference between the latter results is worth noting considering that 22 loci, including the 5 polymorphic loci mentioned, were common to both studies.

In French mouflon populations, genetic diversity was determined for 20 captive individuals (Jardin des Plantes from Paris and INRA from Jouy-en-Josas). Electrophoresis of transferrin and hemoglobin (Nadler et al, 1971; Bunch et al, 1978) showed that both loci were polymorphic and the analysis of red-cell blood groups (Nguyen and Bunch, 1980; Bunch and Nguyen, 1982) indicated a great proximity between domestic sheep and the Corsican mouflon.

In the present paper, we analyse genetic variation in 7 French populations ( 3 captive and 4 wild-living) by blood typing and by electrophoresis of transferrin and hemoglobin. The aim of this study was to determine the effects of founder events 
on the genetic variability of introduced mouflon populations. Genetic variation and structure are discussed in relation to the history of the introductions (origin and number of founder individuals).

\section{MATERIALS AND METHODS}

\section{Animals}

Blood samples were collected from 172 mouflons belonging to 3 captive populations (Paris, Jouy-en-Josas and Lunaret) and 4 feral ones (Corsica, Bauges, Caroux and Italy) (table I).

\section{Genetic systems}

Polymorphism of transferrin and hemoglobin was detected by starch-gel electrophoresis (Nguyen and Bunch, 1980) and by electrofocalisation in the case of hemoglobin. Genetic distances were calculated from allelic frequencies using Gregorius' distance, which satisfies all the properties of a mathematical distance (Gregorius, 1984). Relationships between populations were inferred using the Neighbor program of the Phylip package (Felsenstein, 1990).

Seven genetic systems of red-cell blood groups (OEA: ovine erythrocyte antigens) were analysed: OEA-A, B, C, D, M, R and F30 (Committee on Genetic Nomenclature of Sheep and Goat; Nguyen, 1986). Twenty-five different sheep reagents were tested, corresponding to the factors, $\mathrm{Aa}, \mathrm{Ab}$ and $\mathrm{A} 16$ for $O E A-\mathrm{A} ; \mathrm{Bb}, \mathrm{Bc}, \mathrm{Bd}$, $\mathrm{Be}, \mathrm{Bf}, \mathrm{Bg}, \mathrm{Bh}, \mathrm{Bi}, \mathrm{BF} 3, \mathrm{BF} 35, \mathrm{BF} 38$ and $\mathrm{BF} 418$ for $O E A-B$; $\mathrm{Ca}, \mathrm{Cb}$ and $\mathrm{CF} 5$ for $O E A-C ; \mathrm{Da}$ for $O E A-D ; \mathrm{Ma}$ and $\mathrm{Mb}$ for $O E A-M ; \mathrm{R}$ and $\mathrm{O}$ for $O E A-R ; F 30$ and F275. Hemolytic and hemagglutination techniques were used in blood-group typing (Nguyen, 1972; Nguyen and Ruffet, 1975). For each population, the level of polymorphism was computed by considered a blood factor as polymorphic if its frequency in a population was between 5 and $95 \%$.

\section{Multivariate analyses}

Among multivariate factor methods, correspondence analysis is particularly suited for qualitative data. Raw data are transformed into a contingency table (individuals $\times$ genetic systems). For each blood factor, each individual is assigned the value 1 (positive reaction) or 0 (negative reaction). For the hemoglobin and transferrin loci, each individual is coded 1 for the genotype it presents. Theoretical and practical aspects of this method applied to genetic systems are described in She et al (1987).

A hierarchical classification of the coordinates of individuals on the factor axes was performed from the correspondence analysis according to the method of Roux (1985). Major groups in the classification were retained to produce a dendogram. Group compositions were tested by a contingency table analysis (populations $\times$ group compositions) and the randomness of the distribution (null hypothesis) was assessed by a $\chi$-squared test.

Multivariate analyses were performed on Biomeco software (Lebreton et al, 1990). 
Table I. Origin and composition of the 7 populations of mouflons studied*

\begin{tabular}{|c|c|c|c|}
\hline Population & $\begin{array}{l}\text { Sample size } \\
\quad \text { and sex }\end{array}$ & $\begin{array}{c}\text { Date } \\
\text { of collection }\end{array}$ & $\begin{array}{l}\text { Date and origin of introduction } \\
\text { (number of founder animals) }\end{array}$ \\
\hline $\begin{array}{l}\text { Jardin des Plantes } \\
\text { (Paris) }\end{array}$ & $4^{\mathrm{a}}$ & 1977 & $\begin{array}{l}\text { 1920-1934, animals from Corsica (3), } \\
\text { Sardinia (2), Hamburg (2), Hanover (2) } \\
\text { and unknown origin (4) }\end{array}$ \\
\hline $\begin{array}{l}\text { INRA-CNRZ, } \\
\text { Jouy-en-Josas } \\
\text { (Yvelines) }\end{array}$ & $\begin{array}{ll}2 \mathrm{M} \\
12 & 10 \mathrm{~F}\end{array}$ & 1977 & $\begin{array}{l}\text { 1959-1962, release of animals from } \\
\text { Chambord }^{\text {b }}(5)\end{array}$ \\
\hline $\begin{array}{l}\text { Corsica } \\
(\text { Asco+Bavella })\end{array}$ & $\begin{array}{l}12 \mathrm{M} \\
7 \mathrm{~F}\end{array}$ & $\begin{array}{l}1984 \\
1985 \\
1986 \\
1988 \\
1989\end{array}$ & 7000 to $6000 \mathrm{BC}$, human introduction \\
\hline $\begin{array}{l}\text { Carroux } \\
\text { (Hérault) }\end{array}$ & $\begin{array}{l}39 \mathrm{M} \\
75 \mathrm{~F}\end{array}$ & $\begin{array}{l}1987 \\
1989 \\
1990 \\
1991\end{array}$ & $\begin{array}{l}\text { 1956-1960, release of animals } \\
\text { from Cadarache (Bouches-du-Rhône) (4) } \\
\text { Chambord }^{\text {b }}(10) \text { and Czechoslovakia (5) }\end{array}$ \\
\hline $\begin{array}{l}\text { Zoo de Lunaret } \\
\text { (Hérault) }\end{array}$ & $\begin{array}{l}3 \mathrm{M} \\
12 \mathrm{~F}\end{array}$ & 1988 & $\begin{array}{l}\text { 1976-1979, most animals originated } \\
\text { from Caroux }(6)\end{array}$ \\
\hline $\begin{array}{l}\text { Bauges } \\
\text { (Savoie }+ \\
\text { Haute-Savoie) }\end{array}$ & $\begin{array}{l}1 \mathrm{M} \\
3 \mathrm{~F}\end{array}$ & $\begin{array}{l}1989 \\
1990\end{array}$ & $\begin{array}{l}\text { 1954-1955, release of animals } \\
\text { from Chambord }{ }^{b}(16)\end{array}$ \\
\hline $\begin{array}{l}\text { Italy } \\
\text { (Cuneo, valley } \\
\text { of Stura) }\end{array}$ & $\begin{array}{l}1 \mathrm{M} \\
3 \mathrm{~F}\end{array}$ & 1991 & $\begin{array}{l}\text { Expansion from the Mercantour; } \\
1962, \text { release of animals from } \\
\text { Chambord }^{b}(9)\end{array}$ \\
\hline
\end{tabular}

* Samples from Jardin des Plantes, Zoo de Lunaret and Jouy-en-Josas are captive animals. Data from the files of the Office National de la Chasse. ${ }^{\text {a }}$ Sex not determined. b The population of Chambord (Loir-et-Cher) was founded in 1949 from animals of diverse origins, mainly from Zoo de Vincennes and Jardin des Plantes (Paris), Corsica, Czechoslovakia and Bauges (after 1962).

\section{RESULTS}

\section{Blood proteins}

Table II provides the allelic frequencies for the hemoglobin and transferrin loci in the 7 populations. Four alleles were detected at the transferrin locus, $\operatorname{Trf} D$ being the most common, as in other mouflon populations (Nadler et al, 1971; Stratil and Bobak, 1988). TrfA (present in the Caroux and Italian samples) and $\operatorname{TrfE}$ (present only in the Caroux population) are rare alleles described here for the first time in 
the Corsican mouflon. At the hemoglobin locus, 2 alleles $H b A$ and $H b B$ were scored. The populations of Jouy, Caroux and Lunaret were monomorphic for the $H b B$ allele. This was also the case for the Czechoslovakian (Stratil and Bobak, 1988), Sardinian (Naitana et al, 1990) and Italian (Randi et al, 1991) populations. Finally, $H b A$ was observed only in the populations of Paris, Corsica, Bauges and Italy.

Table II. Allele frequencies at the loci of transferrin (Trf) and hemoglobin $(H b)$.

\begin{tabular}{lcccccccc}
\hline Locus & Allele & \multicolumn{7}{c}{ Population (Sample size) } \\
\cline { 3 - 9 } & & $\begin{array}{c}\text { Paris } \\
(4)\end{array}$ & $\begin{array}{c}\text { Jouy } \\
(12)\end{array}$ & $\begin{array}{c}\text { Corsica } \\
(19)\end{array}$ & $\begin{array}{c}\text { Caroux } \\
(114)\end{array}$ & $\begin{array}{c}\text { Lunaret } \\
(15)\end{array}$ & $\begin{array}{c}\text { Bauges } \\
\text { (4) }\end{array}$ & $\begin{array}{l}\text { Italy } \\
\text { (4) }\end{array}$ \\
\hline \multirow{2}{*}{$T r f$} & $\mathrm{~A}$ & 0 & 0 & 0 & 0.004 & 0 & 0 & 0.125 \\
& $\mathrm{C}$ & 0 & 0 & 0.053 & 0.096 & 0.067 & 0 & 0 \\
& $\mathrm{D}$ & 1 & 1 & 0.947 & 0.896 & 0.933 & 1 & 0.875 \\
& $\mathrm{E}$ & 0 & 0 & 0 & 0.004 & 0 & 0 & 0 \\
& $\mathrm{~A}$ & 0.5 & 0 & 0.1 & 0 & 0 & 0.5 & 0.25 \\
& $\mathrm{~B}$ & 0.5 & 1 & 0.9 & 1 & 1 & 0.5 & 0.75 \\
\hline
\end{tabular}

Genetic differentiation computed using Gregorius' genetic distance yielded distance values between 0 and 0.302 with a mean of 0.176 (table III). From the distance matrix, the neighbour-joining method was used to construct an unrooted network (no assumption of molecular clock) showing the genetic relationships between populations (fig 1). Based on these 2 loci, the Bauges and Paris populations appeared to be closely related. Another cluster included the populations of Corsica, Jouy, Lunaret and Caroux, whereas the Italian sample occupied an intermediate position between the 2 groups.

Table III. Matrix of Gregorius' (1984) genetic distances between populations for the protein data.

\begin{tabular}{lcccccc}
\hline & 1 & 2 & 3 & 4 & 5 & 6 \\
\hline 2 Jouy & 0.250 & & & & & \\
3 Corsica & 0.226 & 0.076 & & & & \\
4 Caroux & 0.252 & 0.052 & 0.075 & & & \\
5 Lunaret & 0.283 & 0.033 & 0.057 & 0.018 & & \\
6 Bauges & 0.000 & 0.250 & 0.226 & 0.302 & 0.283 & \\
7 Italy & 0.187 & 0.187 & 0.200 & 0.185 & 0.187 & 0.187 \\
\hline
\end{tabular}

\section{Blood group antigens}

Among the 25 sheep reagents tested, 23 yielded positive results in the mouflon. The A16 and Bd blood factors were not found while all the 172 mouflons analyzed were F30 positive. The frequencies (percentage of positive reactions) for the 


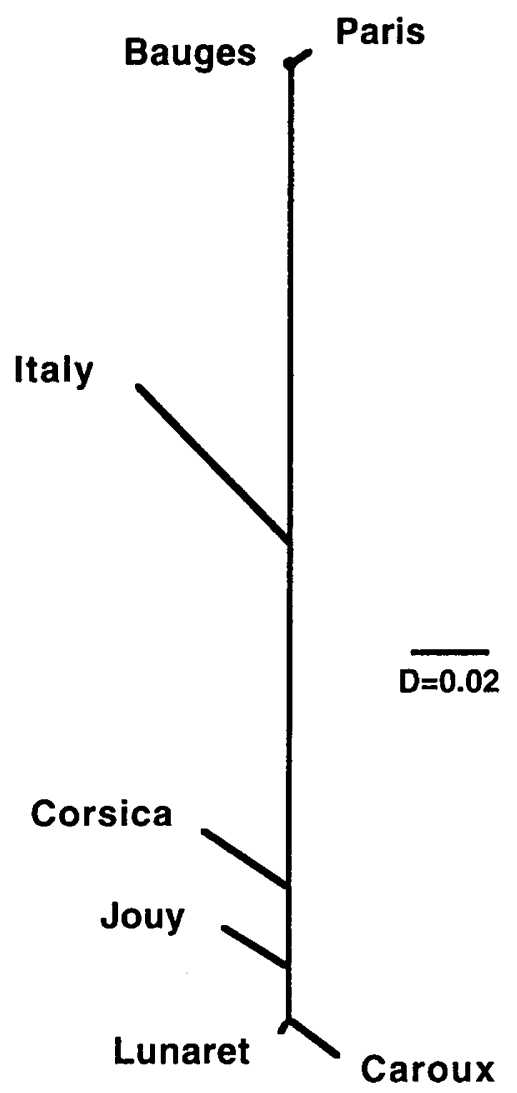

Fig 1. Network obtained from the distance matrix (table II) using the neighbour-joining method.

22 polymorphic reagents are provided in table IV. Large frequency differences were observed between populations, but only the $\mathrm{Bh}$ and Ca factors showed an overall low frequency $(<5 \%)$. Our results are roughly similar to those reported by Nguyen and Bunch (1980) concerning the number and frequency of blood group factors.

For each population, the level of polymorphism, $i e$ the percentage of polymorphic blood factors, was calculated (table IV). The lowest values were observed in populations of Paris, Bauges and Italy (0.26, 0.28 and 0.4 , respectively), which were also the smallest samples analyzed. In the other populations, polymorphism ranged between 0.45 and 0.61 , with the Corsican population showing the highest value.

\section{Multivariate analysis}

Of the 22 blood factors (table IV), BF418, Da and F275 were eliminated from the correspondence analysis due to missing data. The correspondence analysis was then 
Table IV. Frequencies of polymorphic factors of red-cell blood groups (OEA) and percentage of polymorphic systems in the populations (- : factor not tested).

\begin{tabular}{|c|c|c|c|c|c|c|c|c|}
\hline \multirow[t]{2}{*}{ Genetic systems } & \multirow[t]{2}{*}{ Blood factors } & \multicolumn{7}{|c|}{ Populations } \\
\hline & & Paris & Jouy & Corsica & Caroux & Lunaret & Bauges & Italy \\
\hline \multirow{2}{*}{\multicolumn{2}{|c|}{$\begin{array}{l}\text { Sample size } \\
\text { Percentage of polymorphism }\end{array}$}} & 4 & 12 & 19 & 114 & 15 & 4 & 4 \\
\hline & & 0.26 & 0.56 & 0.61 & 0.56 & 0.45 & 0.28 & 0.4 \\
\hline \multirow[t]{2}{*}{ OEA-A } & $\mathrm{Aa}$ & 0 & 0.67 & 1 & 0.9 & 0.6 & 0.5 & 0.25 \\
\hline & $\mathrm{Ab}$ & 0.25 & 0.83 & 0 & 0.28 & 0.53 & 0.75 & 0.75 \\
\hline \multirow[t]{11}{*}{ OEA-B } & $\mathrm{Bb}$ & 0.5 & 0.5 & 0.053 & 0.026 & 0 & 0.25 & 0 \\
\hline & $\mathrm{Bc}$ & 1 & 0.083 & 0.95 & 0.54 & 0.87 & 0 & 0.25 \\
\hline & $\mathrm{Be}$ & 0.5 & 0 & 0 & 0.62 & 0.67 & 1 & 1 \\
\hline & $\mathrm{Bf}$ & 0 & 0.92 & 0.21 & 0.78 & 0.73 & 0.75 & 0.75 \\
\hline & $\mathrm{Bg}$ & 1 & 0 & 0.053 & 0.026 & 0 & 0 & 0 \\
\hline & $\mathrm{Bh}$ & 0 & 0 & 0.053 & 0 & 0 & 0 & 0 \\
\hline & $\mathrm{Bi}$ & 0.5 & 0.92 & 0.11 & 0.53 & 0.73 & 1 & 1 \\
\hline & BF3 & 1 & 0.92 & 0.26 & 0.67 & 0.067 & 0.5 & 0.25 \\
\hline & BF35 & 1 & 0.42 & 0.89 & 0.7 & 0 & 0.5 & 0.5 \\
\hline & BF38 & 0 & 0 & 0.16 & 0.96 & 0 & 0 & 0 \\
\hline & BF418 & - & - & - & 0.87 & - & 0.5 & 0.5 \\
\hline \multirow[t]{3}{*}{ OEA-C } & $\mathrm{Ca}$ & 0 & 0 & 0 & 0.009 & 0 & 0 & 0 \\
\hline & $\mathrm{Cb}$ & 1 & 0.83 & 1 & 0.71 & 0.93 & 1 & 1 \\
\hline & CF5 & 0 & 0 & 0.21 & 0 & 0 & 0 & 0 \\
\hline OEA-D & $\mathrm{Da}$ & 0 & 0.33 & 0.05 & 0.04 & - & 0 & 0 \\
\hline \multirow[t]{2}{*}{ OEA-M } & $\mathrm{Ma}$ & 0 & 1 & 1 & 1 & 1 & 1 & 1 \\
\hline & $\mathrm{Mb}$ & 1 & 0.58 & 0.16 & 0.017 & 0 & 0 & 0.25 \\
\hline \multirow[t]{2}{*}{ OEA-R } & $\mathrm{R}$ & 0.75 & 0.5 & 0.68 & 0.37 & 0.47 & 1 & 0.5 \\
\hline & $\mathrm{O}$ & 0.25 & 0.5 & 0.32 & 0.63 & 0.53 & 0 & 0.5 \\
\hline \multicolumn{2}{|l|}{ F275 } & - & - & - & 0.84 & - & 1 & 1 \\
\hline
\end{tabular}

performed on 21 polymorphic genetic systems (hemoglobin, transferrin and the 19 remaining blood factors, see table IV) yielding 44 variables.

Figure 2 shows the projections ('envelopes' joining points of extreme distribution) of each sample in the plane defined by the first 2 factor axes, which account for $24.5 \%$ of the total variability. The factor axis 1 mainly characterized the individuals from Paris due to the presence of the $\mathrm{Bg}$ and $\mathrm{Mb}$ blood factors, the absence of $\mathrm{Ma}$ and heterozygosity at the hemoglobin locus. The factor axis 2 opposes individuals which do not possess Bf, BF3 and Be and those presenting BF3 and Be. These variables separate the majority of Corsican animals from the populations of Lunaret, Jouy, Italy and Bauges. The individuals from Caroux were distributed all along this axis, and include all the mentioned above. Axis 3 (not shown) isolated 4 individuals from Corsica characterized by the presence of the Bh, BF38 and CF5 blood factors. 


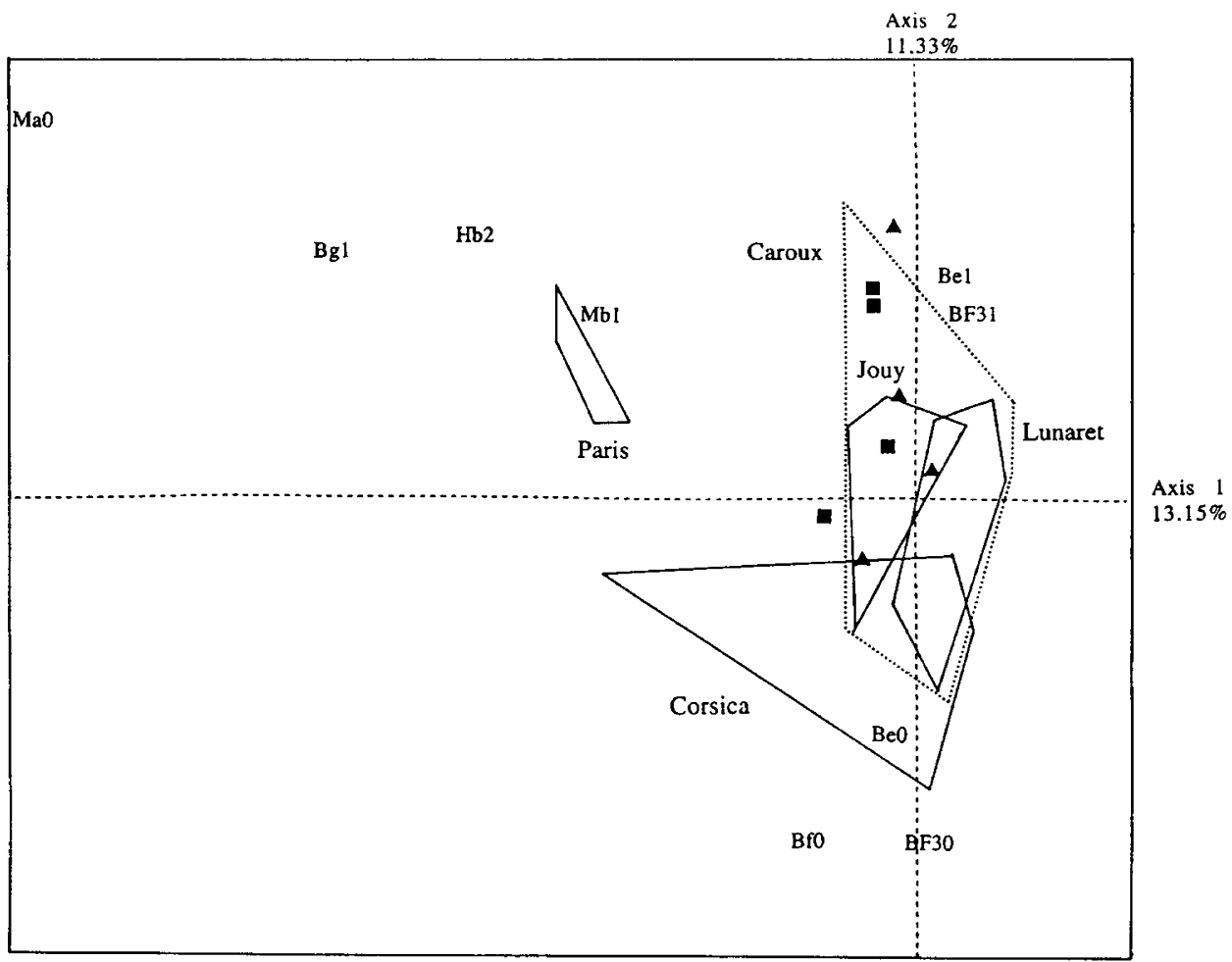

Fig 2. Projection of the cloud of individuals for each sample in the plane defined by the first 2 factor axes of the correspondence analysis: $\mathbf{\Delta}$ : individuals of Italy; $\mathbf{m}$ : individuals of Bauges. The variables showing the greatest contributions to the axes are also represented.

The hierarchical classification was performed on coordinates of individuals on the first 6 principal axes which represented $50.8 \%$ of the overall variability. Five major groups are apparent (fig 3 ) between which individuals are not randomly distributed. Groups A and B which include all individuals from Corsica are the only ones between which the composition was not statistically different $(\chi$-squared $=9.64$, $d f=5, p>0.05)$. On the other hand, the composition of groups $\mathrm{A}+\mathrm{B}, \mathrm{D}$ and $\mathrm{E}$ appeared statistically different $(\chi$-squared $=81.3, d f=18, p<0.001)$. Group C (the sample from Paris) was not included in the test because of its small sample size. Most individuals from Jouy, Bauges and Italy belong to group E. The Caroux and Lunaret samples are similarly distributed in groups A, D and E. 

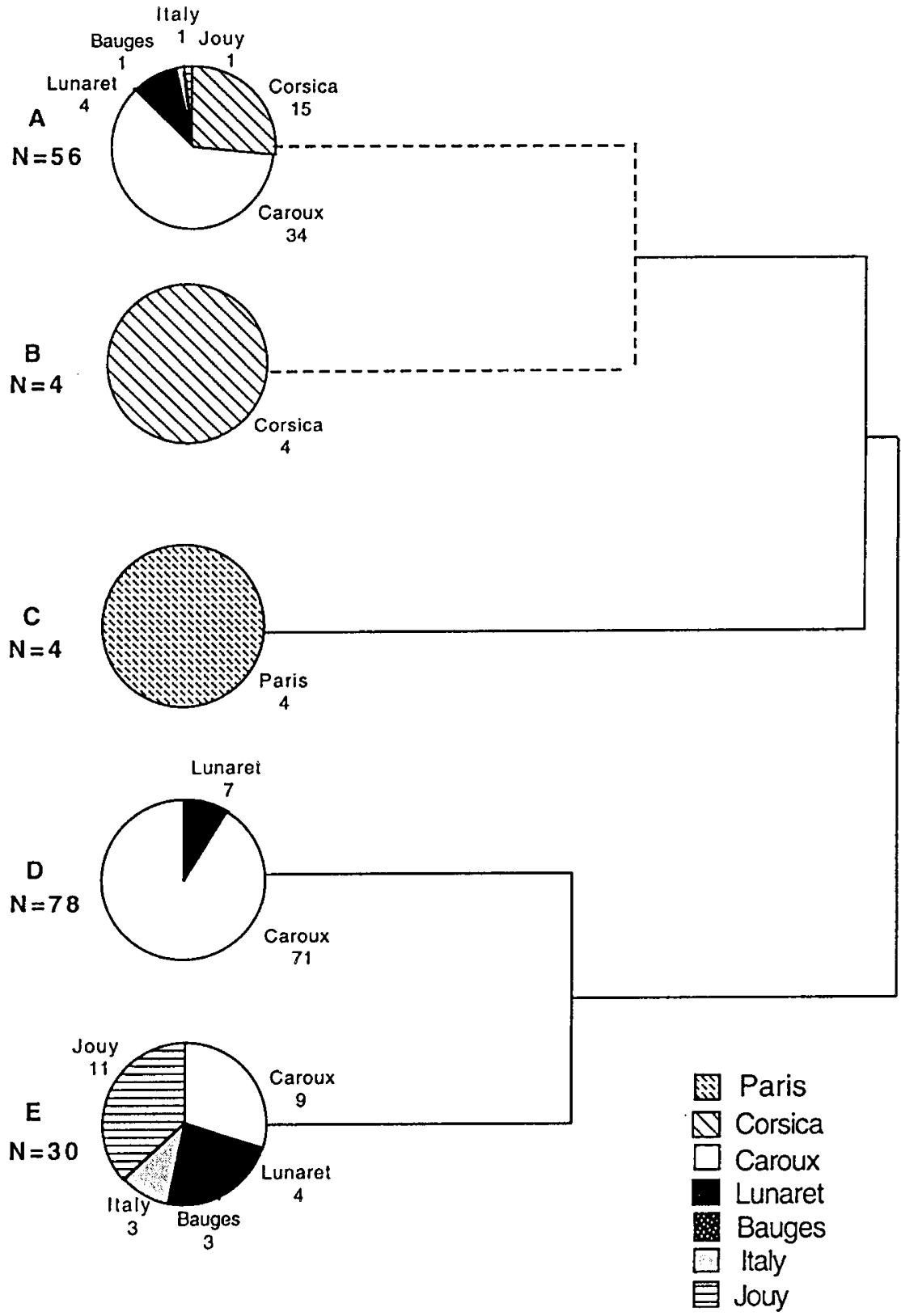

Fig 3. Hierarchical classification based on the coordinates of individuals on the first 6 factor axes of the correspondence analysis. Each circle includes individuals belonging to major dichotomies. The dotted lines indicate that the compositions of groups A and B are not statistically different (see text). 


\section{DISCUSSION}

\section{Maintenance of genetic variability}

Except for the native Corsican population, all the other populations studied were established by releasing a small number of animals either in the wild or in enclosures (see table I). In small founder populations, loss of genetic information is expected due to genetic bottlenecks and subsequent inbreeding. Nevertheless, a clear reduction in genetic variability was not observed in our study between introduced and native mouflon populations. Among the 25 reagents tested, only 2 (Bh and CF5) present in the Corsican population were not recovered in the other samples. The only populations showing a decrease in variability are the 3 (Paris, Bauges and Italy) for which the sample sizes are the smallest (4 individuals). In the larger samples, the level of polymorphism of blood factors (table IV) is similar among captive (Jouy and Lunaret), feral (Caroux) and native (Corsica) populations.

Reduction in genetic variability subsequent to low effective population size is not rare for large mammals reintroduced from refuge zones. This phenomenon has been observed for the fallow deer (Randi and Apollonio, 1988) and for the Alpine Ibex (Stuwe and Scribner, 1989). The maintenance of genetic variability observed in the mouflon populations may be explained by the geographical diversity and genetic divergence of the founder individuals. As seen in table I, French populations always originated from animals coming from localities as diverse as Corsica and Czechoslovakia. The genetic studies performed on Czechoslovakian (Stratil and Bobak, 1988), Austrian (Hartl, 1990) and Italian (Randi et al, 1991) mouflon populations indicated that these populations were genetically differentiated. Such results suggest that the founder mouflons may have been sufficiently divergent genetically to overcome genetic drift and inbreeding at the initial stages of the introduction. This geographical genetic diversity observed in European mouflon populations may be related to the history of introductions which are known to differ according to the regions considered (Tomiczek, 1985; Uloth and Prien, 1985) including breeding with domestic sheep or with Middle-Eastern subspecies of mouflon (Pfeffer, 1984).

\section{Genetic structure and origin of founder animals}

Multivariate analyses (correspondence analysis and hierarchical classification) revealed a genetic classification into 5 major groups (fig 3); the native Corsican sample (all individuals belong to the groups A plus B in figure 3 ) being relatively differentiated from the introduced populations. The pattern of introductions and the origin of founder populations (table I) may provide an explanation for this genetic structure. Most individuals of Italy, Bauges and Jouy, which are classified in the same group ( $\mathrm{E}$ in fig 3), originated from founders, part of which were introduced from Chambord between 1954 and 1962. The population from Paris (group C) appears well differentiated, which may be partly due to a sampling effect but also to its very diverse pool of founders. Finally, the individuals from Caroux are distributed into the same 3 groups (A,D and $\mathrm{E}$ ) as the Lunaret sample which was created with mouflons from the Caroux. 
A correlation between the genetic structure and the origin of founder mouflons implies the persistence for several years of the genetic make-up of the founder animals. Two factors might explain this phenomenon. First the absence of gene flow due to geographical isolation has prevented genetic homogenization. The populations studied are not in contact, either because they are captive or because they live in isolated mountains. The second factor allowing a resilience of the genetic make-up may be the genetic systems under study (blood factors), which are composed of several genetic determinants (haplotype). The genetic structure observed is mostly based on factors of the $\mathrm{B}$ system $\mathrm{Bg}, \mathrm{Be}, \mathrm{Bf}$ and $\mathrm{BF} 3$ in the correspondence analysis) which is known to be controlled by a set of closely linked genes (Grosclaude et al, 1983). The quasi-absence of recombination events may have allowed particular genetic combinations to persist over several generations.

\section{Origin of the mouflon by feralization}

The origin of the Corsican mouflon is not well known. According to paleontological and anatomical data (Poplin, 1979; Vigne, 1983), the mouflon originated from the first domesticated sheep (Neolithic) followed by feralization in the Corsico-Sardinian islands. The emergence of the mouflon would have therefore occurred between 6000 and $4000 \mathrm{BC}$ (Vigne, 1983). Support for this hypothesis was provided by Bunch et al (1978) on the basis of the hemoglobin ( $\beta$ chain) allele distribution. The $H b$ $A$ allele is reported to occur only in sheep and Corsican mouflon, but not in the closest relatives of the European mouflon (Asiatic and Middle-Eastern mouflon). Bunch et al (1978) suggested that the Corsican mouflon originated from an archaic strain of domestic sheep that carried the $H b A$ allele. Until now, the $H b A$ allele has been recorded only in some of the populations of our study (Corsica, Paris, Bauges and Italy) but was not detected in Czechoslovakia (Stratil and Bobak, 1988), Italy (Randi et al, 1991) or Sardinia, where Naitana et al (1990) studied 100 wild mouflons. If the hypothesis of Bunch et al is correct the subsequent disappearance of $H b A$ in Sardinia needs to be postulated.

However, the question arises as to whether $H b A$ recorded in sheep and mouflon corresponds to the same allele. Stratil and Bobak (1988) as well as Naitana et al (1990) have shown by isoelectric focusing and HPLC (reverse-phase high performance liquid chromatography) that $H b B$ of sheep and mouflon are different although they appeared indistinguishable by starch electrophoresis. At present, support for the emergence of the mouflon by feralization requires additional HPLC data establishing the identity of the $H b A$ alleles in sheep and mouflon.

\section{ACKNOWLEDGMENTS}

We would like to thank all our collaborators who have taken part in the collection of samples: MP Battesti, JC Franceschetti, D Roux, J Vitti and the ONC gamekeepers from the BMI Corsica; P Gibert, H Houssin and the personnel of the Bauges reserve; ME Cresci and E Bracco for the Italian sample; JM Cugnasse and M Garcia for the Caroux sample; and $\mathrm{M}$ Gallet and the personnel from the Zoo de Lunaret. We thank J Britton-Davidian and L Ellison for helpful comments on the manuscript. Data analysis was financed by the Office National de la Chasse. This is contribution 94-016 of the Institut des Sciences de l'Evolution, Montpellier. 


\section{REFERENCES}

Bunch TD, Nguyen TC (1982) Blood group comparisons between European mouflon sheep and North American desert bighorn sheep. J Hered 73, 112-114

Bunch TD, Nguyen TC, Lauvergne JJ (1978) Hemoglobins of the Corsico-Sardinian mouflon (Ovis musimon) and their implications for the origin of $H b A$ in domestic sheep (Ovis aries). Ann Génét Sél Anim 10, 503-506

Felsenstein (1990) Phylip, version 4.0, University of Washington, Seattle, WA

Gregorius H (1984) A unique genetic distance. Biometrical $J$ 26, 13-18

Grosclaude F, Lefebvre J, Noé G (1983) Nouvelles précisions sur la carte génétique du système de groupes sanguins B des bovins. Génét Sél Evol 15, 45-54

Hartl GB (1990) Genetische Variabilität beim Muflon (Ovis ammon musimon). Z Jagdwiss 36, 95-103

Lebreton JD, Roux M, Bacou AM, Banco G (1990) Logiciel Biomeco 3.93. Unit Biométrie, CEFE, CNRS

Nadler CF, Woolf A, Harris KE (1971) The transferrins and hemoglobins of bighorn sheep (Ovis canadensis), dall sheep (Ovis dalli) and mouflon (Ovis musimon). Comp Biochem Physiol 40, 567-570

Naitana S, Ledda S, Cocco E, Manca L, Masala B (1990) Hemoglobin phenotypes of the wild European mouflon sheep living on the island of Sardinia. Anim Genet 21, 65-75

Nguyen TC (1972) Les groupes sanguins des ovins. I. Relations entre les groupes sanguins des ovins et des bovins. Ann Génét Sél Anim 4, 363-374

Nguyen TC (1986) Loci for serologic polymorphisms in the Ovicaprinae. In: Standardized Genetic Nomenclature for Sheep and Goats 1986 (Proc COGNOSAG Workshop 1986) Technique et Documentation, Lavoisier, Paris, 53-56

Nguyen TC, Ruffet G (1975) Les groupes sanguins des ovins. II. Facteurs antigéniques supplémentaires dans les systèmes A, B, C et M; estimation des fréquences 'alléliques' aux systèmes $\mathrm{A}, \mathrm{B}, \mathrm{C}, \mathrm{D}, \mathrm{M}$ et $\mathrm{R}$ dans les races françaises : Berrichon-du-Cher, Ile-deFrance et Texel. Ann Génét Sél Anim 7, 145-157

Nguyen TC, Bunch TD (1980) Blood groups and evolutionary relationships among sheep (Ovis aries), domestic goat (Capra hircus), aoudad (Ammotragus lervia) and European mouflon (Ovis musimon). Ann Génét Sél Anim 12, 169-180

ONC (1985) Le mouflon de Corse. Supplément au Bulletin mensuel de l'ONC 88

Pfeffer P (1984) Le mouflon de Corse (Ovis ammon musimon). In: Atlas des mammifères sauvages de France, Société Française pour l'Étude et la Protection des Mammifères, Paris, p 226

Poplin F (1979) Origine du mouflon de Corse dans une nouvelle perspective paléontologique, par marronnage. Ann Génét Sél Anim 11, 133-143

Randi E, Apollonio M (1988) Low biochemical variability in European fallow deer (Dama dama L): natural bottlenecks and the effects of domestication. Heredity 61, 405-410

Randi E, Fusco G, Lorenzini R, Toso S, Tosi G (1991) Allozyme divergence and phylogenetic relationships among Capra, Ovis and Rupicapra (Artiodactyla, Bovidae) Heredity $67,281-286$

Roux M (1985) Algorithmes de classification. Masson, Paris

She JX, Autem M, Kotulas G, Pasteur N, Bonhomme F (1987) Multivariate analysis of genetic exchanges between Solea aegyptiaca and Solea senegalensis (Teleosts, Soleidae). Biol J Lin Soc 32, 357-371

Stratil A, Bobak P (1988) Comparison of biochemical polymorphisms in mouflon and sheep: isoelectric differences in haemoglobins and quantitative variation of mouflon haemopexin. Comp Biochem Physiol 90, 159-162 
Stüwe M, Scribner KT (1989) Low genetic variability in reintroduced alpine ibex (Capra ibex ibex) populations. J Mamm 70, 370-373

Tomiczek H (1985) The muflon (Ovis ammon musimon Schreber, 1782) in the southern and western countries of Europe. In: Northern Wild Sheep and Goat Council, Special Report, 127-132

Uloth W, Prien S (1985) The history of introductions of mouflon sheep (Ovis ammon musimon Schreber, 1782) in central and eastern Europe, and the development and management of these wild sheep populations. In: Northern Wild Sheep and Goat Council, Special Report, 133-137

Vigne JD (1983) Les mammifères post-glaciaires de Corse. Étude archéozoologique. Gallia Préhistoire, XXVI supplément, Editions du CNRS, Paris 